Article

\title{
Phytostabilization of Polluted Military Soil Supported by Bioaugmentation with PGP-Trace Element Tolerant Bacteria Isolated from Helianthus petiolaris
}

\author{
Anabel Saran 1,2@, Valeria Imperato ${ }^{2}$, Lucia Fernandez ${ }^{1}$, Panos Gkorezis ${ }^{2}$, Jan d'Haen ${ }^{3,4}$, \\ Luciano Jose Merini ${ }^{1}$, Jaco Vangronsveld ${ }^{2,5}$ (i) and Sofie Thijs ${ }^{2, *(1)}$ \\ 1 EEA Anguil INTA-CONICET, 6300 Anguil, La Pampa, Argentina; saran.anabel@inta.gob.ar (A.S.); \\ fernandez.lucia@inta.gob.ar (L.F.); merini.luciano@inta.gob.ar (L.J.M.) \\ 2 Environmental Biology, Centre for Environmental Sciences, Hasselt University, Agoralaan Building D, \\ 3590 Diepenbeek, Belgium; valeria.imperato@uhasselt.be (V.I.); panos.gkorezis@uhasselt.be (P.G.); \\ jaco.vangronsveld@uhasselt.be (J.V.) \\ 3 Institute for Material Research (IMO), Hasselt University, Wetenschapspark 1, 3590 Diepenbeek, Belgium; \\ jan.d'haen@uhasselt.be \\ 4 IMEC, Division IMOMEC, Wetenschapspark 1, 3590 Diepenbeek, Belgium \\ 5 Department of Plant Physiology, Faculty of Biology and Biotechnology, Maria Curie Sklodowska University, \\ Akademicka 19, 20-400 Lublin, Poland \\ * Correspondence: sofie.thijs@uhasselt.be; Tel.: +54-9-2302-648363
}

Received: 22 November 2019; Accepted: 14 January 2020; Published: 1 February 2020

check for updates

\begin{abstract}
Lead $(\mathrm{Pb})$ and cadmium $(\mathrm{Cd})$ are major environmental pollutants, and the accumulation of these elements in soils and plants is of great concern in agricultural production due to their toxic effects on crop growth. Also, these elements can enter into the food chain and severely affect human and animal health. Bioaugmentation with plant growth-promoting bacteria (PGPB) can contribute to an environmentally friendly and effective remediation approach by improving plant survival and promoting element phytostabilization or extraction under such harsh conditions. We isolated and characterised $\mathrm{Pb}$ and $\mathrm{Cd}$-tolerant root-associated bacteria from Helianthus petiolaris growing on a $\mathrm{Pb} / \mathrm{Cd}$ polluted soil in order to compose inoculants that can promote plant growth and also ameliorate the phytostabilization or phytoextraction efficiency. One hundred and five trace element-tolerant rhizospheric and endophytic bacterial strains belonging to eight different genera were isolated from the aromatic plant species Helianthus petiolaris. Most of the strains showed multiple PGP-capabilities, ability to immobilise trace elements on their cell wall, and promotion of seed germination. Bacillus paramycoides ST9, Bacillus wiedmannii ST29, Bacillus proteolyticus ST89, Brevibacterium frigoritolerans ST30, Cellulosimicrobium cellulans ST54 and Methylobacterium sp. ST85 were selected to perform bioaugmentation assays in greenhouse microcosms. After 2 months, seedlings of sunflower (H. annuus) grown on polluted soil and inoculated with B. proteolyticus ST89 produced $40 \%$ more biomass compared to the non-inoculated control plants and accumulated $20 \%$ less $\mathrm{Pb}$ and $40 \%$ less $\mathrm{Cd}$ in the aboveground plant parts. In contrast, B. paramycoides ST9 increased the bioaccumulation factor (BAF) of $\mathrm{Pb}$ three times and of $\mathrm{Cd}$ six times without inhibiting plant growth. Our results indicate that, depending on the strain, bioaugmentation with specific beneficial bacteria can improve plant growth and either reduce trace element mobility or enhance plant trace element uptake.
\end{abstract}

Keywords: Bioaugmentation; plant growth promoting bacteria (PGPB); trace elements; $\mathrm{Pb}$ and $\mathrm{Cd}$; polluted soil; phytostabilization 


\section{Introduction}

Trace element pollution of agricultural soils and waters has been dramatically increased during the last few decades [1]. Also, human exposure has risen dramatically as a result of an exponential increase in agricultural production of areas with contaminated soil. In recent years, there has been an increasing ecological and global public health concern associated with environmental contamination by these elements [2]. Trace elements such as $\mathrm{Pb}$ and $\mathrm{Cd}$ are non-essential for living organisms, carcinogenic at low concentrations and are usually originating from mining, smelting, electroplating, petrochemical production [3], and military activities [4].

Due to restrictions on the release of these elements into the environment [5] and the limitations of conventional soil remediation technologies such as high cost, labour intensity, irreversible changes in soil properties, and disturbance of the native soil microflora [6], phytostabilization and phytoextraction received increasing attention as alternative and more environmentally friendly approaches for the remediation of trace element polluted sites $[7,8]$.

Phytostabilization aims to establish a plant cover on polluted sites and to reduce further spread of pollutants and is a common practice around the world to revegetate mine tailings [8,9]. Phytoextraction comprises the process of plant root uptake, root-to-shoot translocation, shoot accumulation and detoxification to concentrate pollutants in harvestable biomass [10,11]. These processes strongly depend on plant growth-promoting bacteria (PGPB), which inhabit the rhizosphere and the internal tissues of plants. Some of the features that these bacteria possess include the production of phytohormones, siderophores, and 1-aminocyclopropane-1-carboxylic acid deaminase (ACCD), as well as nitrogen fixation, solubilisation of insoluble P minerals, and production of antibiotics. Through these mechanisms PGPB can enhance plant tolerance to trace element stress and biomass production [12]. Furthermore, when inoculated into soil (bioaugmentation), such bacteria can influence the bioavailability of trace elements by redox transformations, leading to element mobilization, dissolution, leaching, or immobilization through organic molecule-trace element-binding and precipitation [13].

Sunflower (Helianthus annuus L.) is globally one of most important oilseed crops. The popularity of sunflower is driven by its versatility as oil, seed and as an animal feed. Also due to its high drought tolerance and adaptation to a great variety of soils, the sunflower is suitable for cultivation in many regions of the world and is been spreading to many countries including Asia and Africa [14]. Several studies made on this crop have revealed that several elements, including $\mathrm{Pb}, \mathrm{Cd}$, copper $(\mathrm{Cu})$, zinc $(\mathrm{Zn})$ and cobalt $(\mathrm{Co})$, accumulate at high concentrations in roots and shoots $[15,16]$ reducing plant growth, biomass, grain yield, and crop quality [17]. However, few attempts have yet been made to use PGPB to alleviate the oxidative stress that excess of these trace elements causes in plants and to reduce trace element mobility controlling the entrance of these elements into the food chain. In their last report the Food and Agriculture Organization of the United Nations (FAO) reported the necessity in the upcoming years to ensure food security and a healthy future for all people and the entire planet [18].

Therefore, the aim of this study was to isolate and characterise $\mathrm{Cd}$ - and $\mathrm{Pb}$-tolerant bacteria, to develop inoculants able to enhance plant growth and increase the phytostabilization efficiency of $H$. annuus when cultivated in polluted areas.

\section{Materials and Methods}

\subsection{Isolation of Endophytic and Rhizospheric Trace Element-Tolerant Bacteria}

Endophytic bacteria were isolated from surface-sterilized roots of $H$. petiolaris plants growing in soils spiked with up to $1000 \mathrm{mg} \mathrm{kg}^{-1}$ of $\mathrm{Pb}$ and $100 \mathrm{mg} \mathrm{kg}^{-1}$ of Cd from a previous study Saran et al. (2019) [19]. For surface sterilization, roots were immersed in $70 \%$ ethanol for $10 \mathrm{sec}$, then in $2.5 \%$ sodium hypochlorite for $30 \mathrm{~min}$, and finally rinsed five times in sterile distilled water. To assess sterility, $100 \mathrm{~mL}$ of the water used to rinse the plant tissues were plated onto solid glucose-yeast extract (glucose: $10 \mathrm{~g} \mathrm{~L}^{-1}$; yeast: $5 \mathrm{~g} \mathrm{~L}^{-1}$ ) agar medium; the GY plates were incubated at $30^{\circ} \mathrm{C}$ for two days. One g of root tissue was macerated using sterile mortar and pestle in $200 \mu \mathrm{L}$ of sterile phosphate 
buffer (10 mM PBS, pH 7.4). Tissue extracts $(100 \mu \mathrm{L})$ and their different dilutions were plated onto GY agar medium supplemented with either $10 \mathrm{mg} \mathrm{L}^{-1} \mathrm{Cd}$ or $100 \mathrm{mg} \mathrm{L}^{-1} \mathrm{~Pb}$ (using $\mathrm{CdCl}_{2}, \mathrm{~Pb}_{\left(\mathrm{NO}_{3}\right)_{2}}$ respectively). After incubation at $30^{\circ} \mathrm{C}$ for two days, colonies of varying morphology were picked and repeatedly streaked on GY-trace element containing agar medium until strains were identified as pure. Twenty-two Cd-tolerant isolates and $34 \mathrm{~Pb}$-tolerant isolates were selected and stored on slant agar media for further study.

Isolation of rhizosphere bacteria was performed by washing $1 \mathrm{~g}$ of roots with $\mathrm{NaCl} 0.85 \%$ and $\mathrm{NaCl} 0.85 \%$ /Tween $800.01 \%$ solutions, which were inoculated into sterile GY media supplemented with either $10 \mathrm{mg} \mathrm{L}^{-1} \mathrm{Cd}$ or $100 \mathrm{mg} \mathrm{L}^{-1} \mathrm{~Pb}$. After several rounds of enrichment culture in GY-trace element medium and subsequent isolation and purification in GY-trace element agar plates, $28 \mathrm{Cd}$ tolerant isolates and $21 \mathrm{~Pb}$-tolerant isolates were selected and stored on slant agar media for further study.

\subsection{Genotypic Characterization of $\mathrm{Cd}$ and $\mathrm{Pb}$ Tolerant Strains}

Bacteria were grown for $24 \mathrm{~h}$ at $30^{\circ} \mathrm{C}$ in GY-trace element containing agar medium. Subsequently, total DNA was extracted using a commercial kit (E.Z.N.A; bacterial DNA kit, VWR, Leuven, Belgium). Amplification of the $16 \mathrm{~S}$ rRNA gene was performed in a final volume of $25 \mu \mathrm{L}$ containing $1 \times$ Roche high fidelity PCR buffer, $1.8 \mathrm{mM} \mathrm{MgCl}_{2}, 0.2 \mathrm{mM}$ of each dNTP, $0.2 \mu \mathrm{M}$ of forward and reverse primers

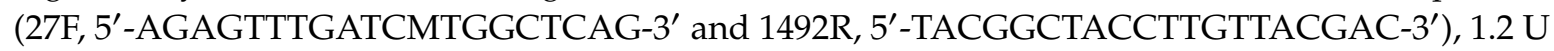
Roche Taq High Fidelity DNA polymerase (Sigma, Leuven, Belgium) and $1 \mu \mathrm{L}$ of DNA $\left(1 \mathrm{ng} \mu \mathrm{L}^{-1}\right)$. PCR reaction conditions were an initial denaturation for 5 min at $95{ }^{\circ} \mathrm{C}, 32$ cycles each consisting of denaturation for $1 \mathrm{~min}$ at $94{ }^{\circ} \mathrm{C}$, primer annealing for $30 \mathrm{~s}$ at $52{ }^{\circ} \mathrm{C}$ and extension at $72{ }^{\circ} \mathrm{C}$ for $3 \mathrm{~min}$ and a final elongation of $10 \mathrm{~min}$ at $72{ }^{\circ} \mathrm{C}$ (Biorad T100, Brussels, Belgium). Quality of PCR products was assessed by electrophoresis (100 V, $30 \mathrm{~min}$ ) on a $2 \%$ agarose gel stained with GelRed (Biotium, USA). Purified PCR products were sent to Macrogen (Amsterdam, The Netherlands) for Sanger sequencing. Partial $16 \mathrm{~S}$ rRNA gene sequences obtained were quality trimmed in Geneious v4.8, and blasted against reference nucleotide sequences present in GenBank, NCBI (Table S1).

\subsection{In-Vitro PGP Activity of the Strains}

Siderophore production was determined in CAS (Chrome Azurol S) agar Petri plates [20]. Plates were incubated for seven days at $29^{\circ} \mathrm{C}$. Bacteria that produced siderophores showed an orange halo around their colonies. Phosphate-solubilizing efficiency of the bacteria was calculated based on the halozones produced around the colonies growing in National Botanical Research Institute's phosphate solid medium prepared according to Nguyen et al. (1992) in Petri plates [21]. Bacterial organic acid production was assessed according to the colorimetric method of Cunningham and Kuiack (1992) [22] after inoculating strains in $800 \mu \mathrm{L}$ of sucrose tryptone medium in 48 well polyvinylchloride (PVC) plates. Bacterial Indole-3-acetic (IAA) production was evaluated in $1 \mathrm{~mL}$ of $1 / 10$ Nutrient Broth with $0.5 \mathrm{~g} \mathrm{~L}^{-1}$ tryptophan. After incubation in 48 well plates, a colorimetric reaction was induced with Salkowski-reagent to assess positive strains [23]. To identify strains that utilize the butylene glycol pathway and produce acetoin, bacteria were inoculated in Methyl Red-Voges Proskauer (MRVP) medium. After $48 \mathrm{~h}$ of incubation in 48 well plates, a colorimetric reaction was induced according to Romick and Fleming (1998) [24]. 1-aminocyclopropane-1-carboxylate (ACC)-deaminase activity was evaluated via a modified protocol based on Belimov et al. (2005) [25]. Washed bacterial cells were resuspended in $1 \mathrm{~mL}$ minimal salts medium with $10 \mathrm{mM}$ ACC as sole nitrogen source in 48 well plates. After 3 days at $30^{\circ} \mathrm{C}$, bacterial cells were resuspended in $0.1 \mathrm{~mL}$ of Tris- $\mathrm{HCl}$ buffer $(\mathrm{pH} 8.5,0.1 \mathrm{M}$ ) and broken by the addition of $1.5 \mu \mathrm{L}$ of toluene. Subsequently, $1.5 \mu \mathrm{L}$ of $0.5 \mathrm{M}$ ACC and $100 \mu \mathrm{L}$ of $0.1 \mathrm{M}$ Tris-HCl buffer ( $\mathrm{pH} 8.5,0.1 \mathrm{M}$ ) were added to prompt ACC deaminase activity, which was stopped by adding $0.5 \mathrm{~mL}$ of $0.56 \mathrm{~N} \mathrm{HCl}$ to check visually the presence of ACC deaminase. Biofilm formation was examined following the method described by O'Toole et al. (2000) [26]. Selected strains were grown on biofilm growth medium (Luria-Bertani, plus $1 \mathrm{mM} \mathrm{MgSO}_{4}$ and $0.1 \%$ glucose) in 24 well plates incubated at $29^{\circ} \mathrm{C}$ without shaking for $48 \mathrm{~h}$. Biofilms were detected by staining with crystal violet 
$0.1 \% \mathrm{w} / \mathrm{v}$. For all the assays not inoculated media were used as a negative control and three replicates were performed per strain tested.

\subsection{In-Vitro Trace Element Uptake by Bacteria in Liquid Cultures-Scanning Electron Microscopy (SEM-EDX) Analysis}

Batch studies were conducted using $50 \mathrm{~mL}$ Falcon tubes that contained $25 \mathrm{~mL}$ GY rich medium supplemented with $10 \mathrm{mg} \mathrm{L}^{-1}$ of $\mathrm{Cd}$ and $100 \mathrm{mg} \mathrm{L}^{-1}$ of $\mathrm{Pb}\left(\mathrm{CdCl}_{2}, \mathrm{~Pb}\left(\mathrm{NO}_{3}\right)_{2}\right)$. All tubes were inoculated with $1 \mathrm{~mL}$ of a bacterial cell suspension (optical density at $600 \mathrm{~nm}=1$ ), which was previously grown in GY medium at $28^{\circ} \mathrm{C}$ for $24 \mathrm{~h}$. Samples were incubated at $28^{\circ} \mathrm{C}$ and $100 \mathrm{rpm}$ on an orbital shaker. In order to estimate the amounts of trace elements retained by bacterial cells, the trace element concentrations were determined in the supernatant after $72 \mathrm{~h}$ of incubation by inductively coupled plasma-atomic emission spectrometry (ICP-OES, Agilent Technologies, 700 series, Belgium). Cultures were first centrifuged $15 \mathrm{~min}$ at $4800 \mathrm{rpm}$. One aliquot of supernatant was filtered $(0.22 \mu \mathrm{m})$ and used for element determination. Media without the trace elements and media with the elements but not inoculated with bacteria were used as negative controls [27]. For the visualization of bacterial structure, bacterial pellets were washed 3 times with $0.01 \mathrm{M}$ phosphate-buffered saline buffer (PBS, pH 7.0) to remove unbound metals, sugars and proteins. Pellets were resuspended in $2 \%$ glutaraldehyde for $1 \mathrm{~h}$ at room temperature. Afterwards, bacterial samples were centrifuged for $3 \mathrm{~min}$ at $3000 \mathrm{rpm}$ and pellets were washed 3 times with milli-Q water. One $\mu \mathrm{L}$ of sample was placed on a sample holder, in carbon conductive tape. Then, samples were coated $30 \mathrm{~s}$ with a $15 \mathrm{~nm}$ gold layer and analysed using a Scanning Electron Microscope (FEI Quanta 200F FEG-SEM with Thermo Fisher Pathfinder Alpine EDS system with UltraDry Premium (60mm2 active area) EDS detector). Images were taken using an accelerating voltage of $12.5 \mathrm{kV}$.

\subsection{In-Vitro Inoculation on Vertical Agar Plates (VAPs), Germination and Growth Promotion}

Seeds of $H$. annuus were sterilized before inoculation by shaking them in $70 \%$ ethanol for $5 \mathrm{~min}$, followed by $5 \%$ hypochlorite for $5 \mathrm{~min}$, and rinsing five times in sterile, deionised water. Inoculation cultures were prepared by growth in GY-trace element medium at $30{ }^{\circ} \mathrm{C}$ for $48 \mathrm{~h}$. Cultures were centrifuged, and pellets were washed twice in sterile $10 \mathrm{mM} \mathrm{MgSO}_{4}$ buffer before being thoroughly resuspended in $10 \mathrm{~mL}$ of the saline buffer until an optical density of 1 at $600 \mathrm{~nm}\left(\approx 10^{9} \mathrm{CFU} \mathrm{mL} \mathrm{mL}^{-1}\right)$ [10]. Fifteen seeds were incubated for $60 \mathrm{~min}$ at $29^{\circ} \mathrm{C}$ on an orbital shaker fully immersed in $10 \mathrm{~mL}$ bacterial culture before sowing them in Petri dishes containing a layer of sterile paper and $10 \mathrm{~mL}$ of sterile deionised water. Germination was evaluated after $48 \mathrm{~h}$. Three germinated seeds were transferred in Vertical Agar Plates containing Murashige and Skoog basal salts medium and held vertically for two weeks in a growth chamber $\left(16: 8 \mathrm{light} /\right.$ dark, photoperiod; $25^{\circ} \mathrm{C} / 19{ }^{\circ} \mathrm{C} ; 400 \mu \mathrm{M} \mathrm{cm}^{-2} \mathrm{~s}^{-1}$ PAR; $60 \%$ relative humidity). Three replicates were performed per strain. Biomass parameters as root and shoot length and fresh and dry weight (DW) were determined after this incubation time.

\subsection{Bioaugmentation in Microcosm Assays, Growth Promotion and Element Bio-Accumulation}

Germination of commercially available H. annuus seeds (EEA-INTA, Anguil, Argentina) was performed in germination trays containing commercial growth substrate (Asef, Osmocote) and controlled conditions of temperature, humidity and watering $\left(25^{\circ} \mathrm{C}\right.$ day $/ 19{ }^{\circ} \mathrm{C}$ night; $60 \%$ relative humidity; $500 \mathrm{~mL}$ per day spray watering; PAR $=400 \mu \mathrm{mol} \mathrm{cm}^{-2} \mathrm{~s}^{-1}$ ) in the greenhouse. After 25 days each substrate block was transplanted to pots containing two litres of bulk military polluted soil from North-East Belgium. The physicochemical properties of the sediments and total trace element concentrations are given in Table 1. 
Table 1. Physicochemical properties and total cadmium $(\mathrm{Cd})$, copper $(\mathrm{Cu})$, lead $(\mathrm{Pb})$, and zinc $(\mathrm{Zn})$ concentrations of the military soil used in the microcosms assay.

\begin{tabular}{|c|c|c|c|}
\hline \multicolumn{4}{|c|}{ Physicochemical properties } \\
\hline Texture (\%) & Conductivity $\left(\mu \mathrm{S} \mathrm{cm}^{-1}\right)$ & CEC (Meq $\left.100 \mathrm{~g}^{-1} \mathrm{DW}\right)$ & $\mathrm{pH}$ \\
\hline sandy-loam & $340 \pm 1.2$ & $9.2 \pm 0.2$ & $6.2 \pm 0.8$ \\
\hline \multicolumn{4}{|c|}{ Trace element concentration $\left(\mathrm{mg} \mathrm{kg}^{-1}\right)$} \\
\hline $\mathrm{Cd}$ & $\mathrm{Cu}$ & $\mathrm{Pb}$ & $\mathrm{Zn}$ \\
\hline $0.42 \pm 1.35$ & $1.02 \pm 1.16$ & $5.48 \pm 0.89$ & $12.43 \pm 20.07$ \\
\hline \multicolumn{4}{|c|}{ Values are mean \pm S.E. $(n=24)$} \\
\hline
\end{tabular}

The pot experiment tested the effects of six bacterial strains on the growth and metal accumulation of $H$. annuus seedlings with 6 replications and grown in polluted soil (36 pots). After one week of acclimatization, plants were inoculated with $10 \mathrm{~mL}$ of bacterial culture. Inoculation cultures were prepared by growing bacteria in GY-trace element broth at $30^{\circ} \mathrm{C}$ for $48 \mathrm{~h}$. Cultures were centrifuged, and cell pellets were washed twice in sterile $10 \mathrm{mM}$ magnesium sulphate buffer, before being thoroughly suspended in $10 \mathrm{~mL}$ of the saline buffer until an optical density of 1 at $600 \mathrm{~nm}$ [10].

Thirty five days after inoculation, plants were harvested from the pots and roots were thoroughly washed with sterile water to remove any soil particles. Mouth masks were used to avoid human hazard and the wash water was placed in special containers. Samples were oven-dried $\left(60^{\circ} \mathrm{C}\right.$ for 1 week), weighed, digested with $70 \% \mathrm{HNO}_{3}$ in a heat block and dissolved in $5 \mathrm{~mL}$ of $2 \% \mathrm{HCl}$. Trace element concentrations in shoots and roots of $H$. annuus were then determined using inductively coupled plasma-atomic emission spectrometry (ICP-OES, Agilent Technologies, 700 series, Hasselt, Belgium). Blanks (only $\mathrm{HNO}_{3}$ ) and standard references (NIST Spinach 1570a) were included. Bio-accumulation factors (BAF) were calculated by dividing the total contents of elements in the plant tissue by the total contents of element in the soil [28].

\subsection{Bacterial Survival and Colonization of Plant Tissues in Microcosms-ARISA}

DNA extraction from root endophytes was performed by using Invisorb Spin Plant Mini Kit (Stratec Biomedical AG, Berlin, Germany) and soil DNA extractions were done by using the DNeasy PowerSoil Isolation kit (Qiagen, Germantown, MD, USA). Internal transcribed spacer (ITS) regions between 16S rRNA and 23S rRNA were amplified by PCR using ITSF (5-GTCGTAACAAGGTAGCCGTA-3) and ITSReub (5-GCCAAGGCATCCACC-3) primers as previously described by Cardinale et al., (2004) [29]. After amplification, samples were loaded onto Agilent DNA 1000 Chips and analysed using the Agilent 2100 Bioanalyzer ${ }^{\circledR}$ (Agilent Technologies, Santa Clara, CA, USA). Expert Software (Agilent Technologies) was used to digitalize the ARISA fingerprints, resulting in electropherograms in ASCII formats that were processed using the StatFingerprints package [30] in $R \times 64$ 3.4.3. Profiles obtained were compared with the profile of the pure inoculated strain.

\subsection{Statistical Analysis}

Data were analysed by using analysis of variance (ANOVA). When ANOVA showed treatment effect, the Least Significant Difference (LSD) test was applied to make comparisons between the means at $p<0.05$. ARISA results were analyses using Fingerprint Library in the 2.13 .0 version of the R project (The R Foundation for Statistical Computing, Vienna, Austria).

\section{Results}

\subsection{Isolation of Endophytic and Rhizospheric Trace Element-Tolerant Bacteria}

A total of 105 morphologically different strains were isolated, genotypically identified and subsequently characterized. Fifty-three strains were tolerant to $100 \mathrm{mg} \mathrm{L}^{-1} \mathrm{~Pb}, 22$ from the rhizosphere 
and 31 root endophytes. Forty-nine strains were tolerant to $10 \mathrm{mg} \mathrm{kg}^{-1} \mathrm{Cd}$, of which 28 from the rhizosphere and 21 root endophytes.

\subsection{Genotypic Characterization of $C d$ and Pb-Tolerant Strains}

Among the 105 morphotypes isolated, 29 different bacteria were identified. Fifteen were $\mathrm{Pb}$ tolerant and $14 \mathrm{Cd}$ tolerant. Figure 1 shows the percentages of presence of each strain in the compartment from which it was isolated. Nine genera were identified, which included Bacillus (68\%), Brevibacterium (3\%), Cellulosimicrobium (3\%), Gordonia (2\%), Pseudobacter (5\%), Rhizobium (3\%), Cupriavidus (3\%), Klebsiella $(2 \%)$, and Methylobacterium (3\%).

Some strains belonging to the Bacillaceae family, including B. cereus ST10/ST60, B. paramycoides ST9/ST98, B. tropicus ST22/ST77, B. proteoliticus ST4/ST89 show tolerance to both elements Cd and Pb, whereas B. proteoliticus ST4, B. safensis ST11, B. subtilis ST7, B. tropicus ST22 were isolated from both, rhizosphere and root endosphere.

Rhizospheric- $\mathrm{Pb}$

A

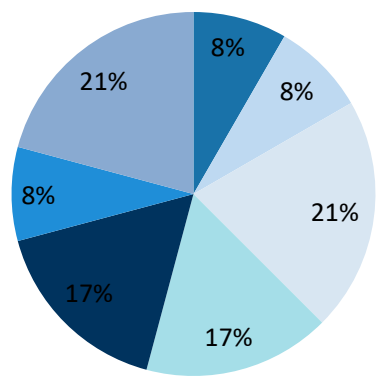

Endophytic- $\mathrm{Pb}$

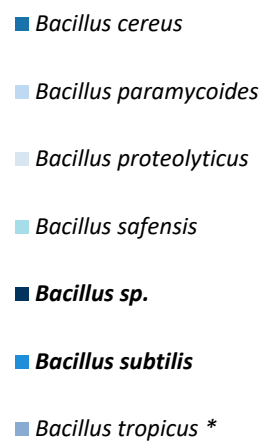

Bacillus tropicus *

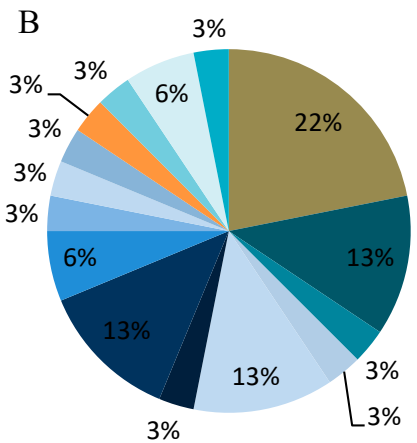

$$
\text { . Bar }
$$

- Cellulosimicrobium cellulans

Endophytic-Cd

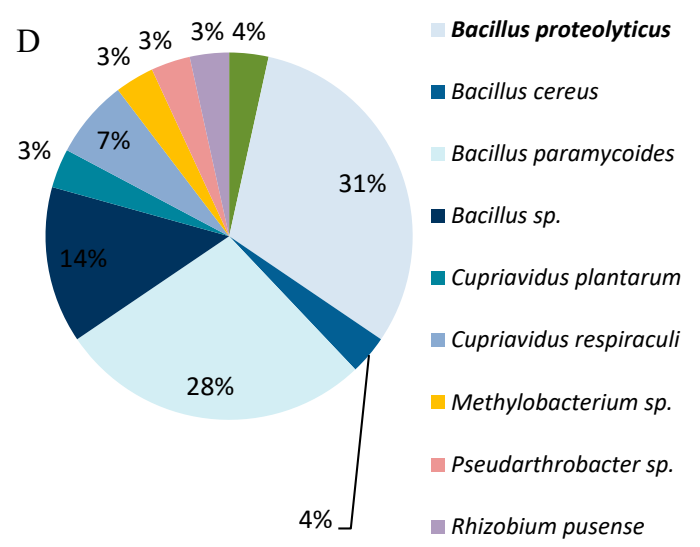

Brevibacterium

frigoritolerans

- Bacillus dentrensis

- Bacillus proteolyticus

Bacillus safensis

- Bacillus simplex

- Bacillus sp.

Bacillus subtilis

- Bacillus tequilensis

Bacillus tropicus*
Rhizospheric-Cd

C

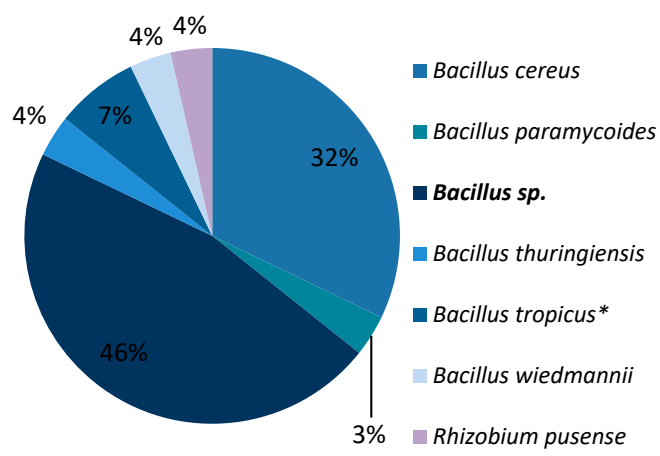

Figure 1. (A) Root rhizospheric and (B) endophytic $\mathrm{Pb}$ tolerant bacterial; and (C) root rhizospheric and

(D) endophytic Cd tolerant bacterial strains; isolated onto heterotrophic glucose-yeast medium, from roots of $H$. petiolaris plants, grown in polluted soils.

\subsection{In-Vitro PGP Activity of the Strains}

The in vitro PGP traits of 28 bacterial isolates are shown in Table 2. Twelve strains were positive for all the qualitative PGP traits tested. Bacillus aryabhattai ST25, Brevibacterium frigoritolerans ST30 and Klebsiella varicola ST106 exhibited the highest capacities to solubilise tricalcium phosphate. Only 
two strains, Bacillus cereus ST10 and Bacillus wiedmannii ST29 were able to produce siderophores. IAA production was detected in six isolates, ranging from 25.94 to $81.47 \mu \mathrm{g} \mathrm{mL}^{-1}$ and Bacillus cereus ST10 was one of the highest biofilm producers.

Table 2. Plant growth-promoting properties of trace element-tolerant bacteria.

\begin{tabular}{|c|c|c|c|c|c|c|c|c|c|}
\hline Strain & ACCD & Acetoin & a $\mathrm{OA}$ & b P-Solub. & b SID & ${ }^{\mathrm{c}}$ IAA & ${ }^{\mathrm{d}}$ Biofilm & $\mathrm{pH}$ & $\begin{array}{l}{ }^{\mathrm{e}} \text { Element } \\
\text { Conc. }\end{array}$ \\
\hline \multicolumn{10}{|l|}{ Lead tolerant } \\
\hline Bacillus sp. ST1 & + & + & + & $0.06 \pm 0.01 *$ & $0.16 \pm 0.01 * *$ & $0.00 \pm 0.00$ & $0.01 \pm 0.00$ & $4.27 \pm 0.18^{*}$ & $5.91 \pm 0.05^{* *}$ \\
\hline Bacillus proteoliticus ST4 & + & + & + & $0.06 \pm 0.01 *$ & $0.26 \pm 0.02 * *$ & $43.61 \pm 1.03 *$ & $0.03 \pm 0.00^{*}$ & $4.23 \pm 0.28 *$ & $5.67 \pm 0.05 *$ \\
\hline Bacillus subtilis ST7 & - & + & - & $0.23 \pm 0.01 * *$ & $0.00 \pm 0.00$ & $0.00 \pm 0.00$ & $0.08 \pm 0.02 *$ & $4.22 \pm 0.08 *$ & $6.31 \pm 0.09 * *$ \\
\hline Bacillus paramycoides ST9 & + & + & + & $0.19 \pm 0.01 * *$ & $0.16 \pm 0.01$ & $0.00 \pm 0.00$ & $0.02 \pm 0.00$ & $4.20 \pm 0.15^{*}$ & $5.85 \pm 0.07^{* *}$ \\
\hline Bacillus cereus ST10 & + & + & + & $0.09 \pm 0.01 *$ & $0.18 \pm 0.01 * *$ & $0.00 \pm 0.00$ & $0.02 \pm 0.00$ & $4.16 \pm 0.07 *$ & $6.19 \pm 0.05^{* *}$ \\
\hline Bacillus safensis ST11 & - & + & + & $0.08 \pm 0.01 *$ & $0.00 \pm 0.00$ & $0.00 \pm 0.00$ & $0.00 \pm 0.00$ & $4.15 \pm 0.07^{*}$ & $6.02 \pm 0.04 * *$ \\
\hline Bacillus tropicus ST22 & + & + & + & $0.06 \pm 0.01 *$ & $0.20 \pm 0.01$ ** & $0.00 \pm 0.00$ & $0.01 \pm 0.00$ & $4.21 \pm 0.18^{*}$ & $6.01 \pm 0.07^{* *}$ \\
\hline Bacillus aryabhattai ST25 & + & - & + & $0.34 \pm 0.02 * *$ & $0.00 \pm 0.00$ & $0.00 \pm 0.00$ & $0.03 \pm 0.00$ & $4.21 \pm 0.32 *$ & $6.03 \pm 0.05^{* *}$ \\
\hline $\begin{array}{c}\text { Brevibacterium } \\
\text { frigoritolerans ST30 }\end{array}$ & - & + & + & $0.37 \pm 0.02 * *$ & $0.00 \pm 0.00$ & $0.00 \pm 0.00$ & $0.02 \pm 0.00$ & $4.26 \pm 0.18^{*}$ & $5.20 \pm 0.12 *$ \\
\hline Bacillus wiedmannii ST29 & + & + & + & $0.05 \pm 0.01 *$ & $0.53 \pm 0.04^{* *}$ & $0.00 \pm 0.00$ & $0.01 \pm 0.00$ & $4.25 \pm 0.04 *$ & $5.09 \pm 0.08^{*}$ \\
\hline Bacillus tequilensis ST34 & - & + & - & $0.04 \pm 0.00^{*}$ & $0.14 \pm 0.01 * *$ & $0.00 \pm 0.00$ & $0.03 \pm 0.00 *$ & $4.254 \pm 0.08^{*}$ & $5.30 \pm 0.10^{*}$ \\
\hline Bacillus dentrensis ST38 & - & + & - & $0.05 \pm 0.01 *$ & $0.11 \pm 0.01 *$ & $0.00 \pm 0.00$ & $0.02 \pm 0.00$ & $4.17 \pm 0.07^{*}$ & $6.58 \pm 0.22 * *$ \\
\hline Bacillus simplex ST43 & + & - & + & $0.01 \pm 0.00$ & $0.00 \pm 0.00$ & $54.30 \pm 2.08 *$ & $0.02 \pm 0.00$ & $4.24 \pm 0.08^{*}$ & $5.79 \pm 0.53^{*}$ \\
\hline Gordonia terrae ST51 & + & - & + & $0.08 \pm 0.01 *$ & $0.22 \pm 0.02 * *$ & $0.00 \pm 0.00$ & $0.04 \pm 0.00 *$ & $4.18 \pm 0.07 *$ & $8.22 \pm 0.432 * *$ \\
\hline $\begin{array}{l}\text { Cellulosimicrobium } \\
\text { cellulans-ST54 }\end{array}$ & + & + & + & $0.10 \pm 0.01 *$ & $0.00 \pm 0.00$ & $0.00 \pm 0.00$ & $0.07 \pm 0.02 *$ & $4.21 \pm 0.27^{*}$ & $6.22 \pm 0.12 * *$ \\
\hline Negative control (GYPb) & - & - & - & $0.00 \pm 0.00$ & $0.00 \pm 0.00$ & $0.00 \pm 0.00$ & $0.01 \pm 0.00$ & $6.08 \pm 0.02$ & $0.49 \pm 0.08$ \\
\hline \multicolumn{10}{|l|}{ Cadmium tolerant } \\
\hline Bacillus cereus ST60 & + & + & + & $0.01 \pm 0.00$ & $0.10 \pm 0.01 *$ & $0.00 \pm 0.00$ & $0.29 \pm 0.06^{* *}$ & $5.08 \pm 0.35^{*}$ & $7.67 \pm 0.33^{*}$ \\
\hline Bacillus tropicus ST77 & + & + & + & $0.00 \pm 0.00$ & $0.38 \pm 0.03^{* *}$ & $50.08 \pm 2.00 * *$ & $0.03 \pm 0.00^{*}$ & $4.97 \pm 0.027^{*}$ & $7.89 \pm 0.09$ \\
\hline Rhizobium pusense ST80 & - & - & + & $0.15 \pm 0.01 * *$ & $0.00 \pm 0.00$ & $0.00 \pm 0.00$ & $0.05 \pm 0.00 *$ & $6.83 \pm 0.44$ & $3.48 \pm 0.05^{* *}$ \\
\hline Methylobacterium ST85 & + & + & + & $0.20 \pm 0.01$ ** & $0.00 \pm 0.00$ & $0.00 \pm 0.00$ & $0.01 \pm 0.00$ & $6.98 \pm 0.42$ & $5.00 \pm 0.12 * *$ \\
\hline Pseudobacter sp. ST86 & + & + & + & $0.26 \pm 0.02 * *$ & $0.00 \pm 0.00$ & $30.25 \pm 1.98^{*}$ & $0.03 \pm 0.00^{*}$ & $6.05 \pm 0.26$ & $4.08 \pm 0.13 * *$ \\
\hline Bacillus sp. ST87 & - & + & + & $0.08 \pm 0.01 *$ & $0.10 \pm 0.01 *$ & $0.00 \pm 0.00$ & $0.04 \pm 0.00^{*}$ & $4.70 \pm 0.15^{*}$ & $7.98 \pm 0.21$ \\
\hline Bacillus proteolyticus ST89 & + & + & + & $0.03 \pm 0.00$ & $0.38 \pm 0.03^{* *}$ & $0.00 \pm 0.00$ & $0.13 \pm 0.02 *$ & $4.99 \pm 0.28 *$ & $7.74 \pm 0.21 *$ \\
\hline Bacillus cereus ST90 & + & + & + & $0.12 \pm 0.01 *$ & $0.60 \pm 0.04^{* *}$ & $0.00 \pm 0.00$ & $0.04 \pm 0.00 *$ & $4.89 \pm 0.019^{*}$ & $6.29 \pm 0.14^{*}$ \\
\hline Achomobacter sp. ST95 & - & + & + & $0.10 \pm 0.01 *$ & $0.24 \pm 0.02 * *$ & $0.00 \pm 0.00$ & $0.10 \pm 0.02 *$ & $6.98 \pm 0.38$ & $4.87 \pm 0.28 * *$ \\
\hline Bacillus paramycoides ST98 & + & + & + & $0.02 \pm 0.00$ & $0.00 \pm 0.00$ & $0.00 \pm 0.00$ & $0.05 \pm 0.00^{*}$ & $4.97 \pm 0.15^{*}$ & $7.87 \pm 0.14^{*}$ \\
\hline Cuproidus plantarum ST102 & + & + & + & $0.09 \pm 0.01 *$ & $0.31 \pm 0.02 * *$ & $25.94 \pm 1.02 *$ & $0.02 \pm 0.00$ & $4.86 \pm 0.13 *$ & $7.87 \pm 0.9^{*}$ \\
\hline Klebsiella variicola ST106 & + & + & + & $0.36 \pm 0.02 * *$ & $0.00 \pm 0.00$ & $81.47 \pm 4.55^{* *}$ & $0.07 \pm 0.02 *$ & $3.57 \pm 0.17^{* *}$ & $7.95 \pm 0.12$ \\
\hline Negative control (GYCd) & - & - & - & $0.00 \pm 0.00$ & $0.00 \pm 0.00$ & $0.00 \pm 0.00$ & $0.00 \pm 0.00$ & $6.6 \pm 0.03$ & $8.27 \pm 0.12$ \\
\hline
\end{tabular}

Values are mean \pm S.E. $(n=3) ;{ }^{\text {a }}$ Organic acid; ${ }^{\mathrm{b}}$ solubilized area $\left(\mathrm{cm}^{2}\right) ;{ }^{\mathrm{c}} \mu \mathrm{g}$ IAA mL ${ }^{-1}$ of medium; ${ }^{\mathrm{d}}$ Measured by optical density (OD600); ${ }^{\mathrm{e}} \mu \mathrm{g} \mathrm{mL} \mathrm{m}^{-1}$ metal in supernatant; + positive; - negative. Values in the same column followed by a * are significantly different from the control at $p \leq 0.05$ by Anova and Tukey test. Values with different number of * are significantly differents.

\subsection{In-Vitro Trace Element Uptake in Culture Media and Scanning Electron Microscopy (SEM-EDX) Analysis}

All $\mathrm{Pb}$ tolerant strains decreased the $\mathrm{pH}$ of the medium after $48 \mathrm{~h}$ of incubation. Due to this, $\mathrm{Pb}$ solubility and its concentration in the supernatant increased (Table 2). Gordonia terrae ST51 was the strain that solubilized $\mathrm{Pb}$ the most, eight times more than the negative control and between 2 and 3 times more than the other strains $(p<0.05)$. Some Cd tolerant strains (e.g., Klebsiella varicola ST106 and Cupriavidus plantarum ST102) acidified the medium and increased the Cd concentration in the supernatant. However, some other strains (e.g., Rhizobium pusense ST80, Pseudobacter sp. ST89 and Achomobacter sp. ST95) increased the Cd concentration in the supernatant with about $50 \%$ compared with the negative control although the $\mathrm{pH}$ did not change.

Interaction between trace elements and other components of the medium is playing an important role in the sequestration of the trace elements. If we compare the nominal concentrations in the growth medium, $10 \mathrm{mg} \mathrm{L}^{-1} \mathrm{Cd}$ and $100 \mathrm{mg} \mathrm{L}^{-1} \mathrm{~Pb}$, with the trace element concentrations in the supernatant of negative controls (Table 2), only $0.5 \%$ of the $\mathrm{Pb}$ added to the medium is available in the supernatant at the conditions established. 
Bacillus paramycoides ST4, Brevibacterium frigoritolerans ST30, Bacillus wiedmannii ST29, Cellulosimicrobium cellulans ST54, Methylobacterium sp. ST85 and Bacillus proteolyticus ST9 were selected to visualize its structure and elements interaction by SEM-EDX (Figure 2). These strains were the most plant growth promoting, did not have adverse effects on seed germination and developed well in vitro. It is clear that $\mathrm{Cd}$ and $\mathrm{Pb}$ were present in/on the bacterial cell wall. The highest signal intensity of $\mathrm{Pb}$ was found around B. paramycoides ST4 strains, while around Brevibacterium frigoritolerans $\mathrm{ST} 30$ the signal intensity of $\mathrm{Pb}$ was half of it and $\mathrm{Pb}$ was not detected in Cellulosimicrobium cellulans. The biofilm capability of Cellulosimicrobium cellulans made it difficult to visualize individual cells.

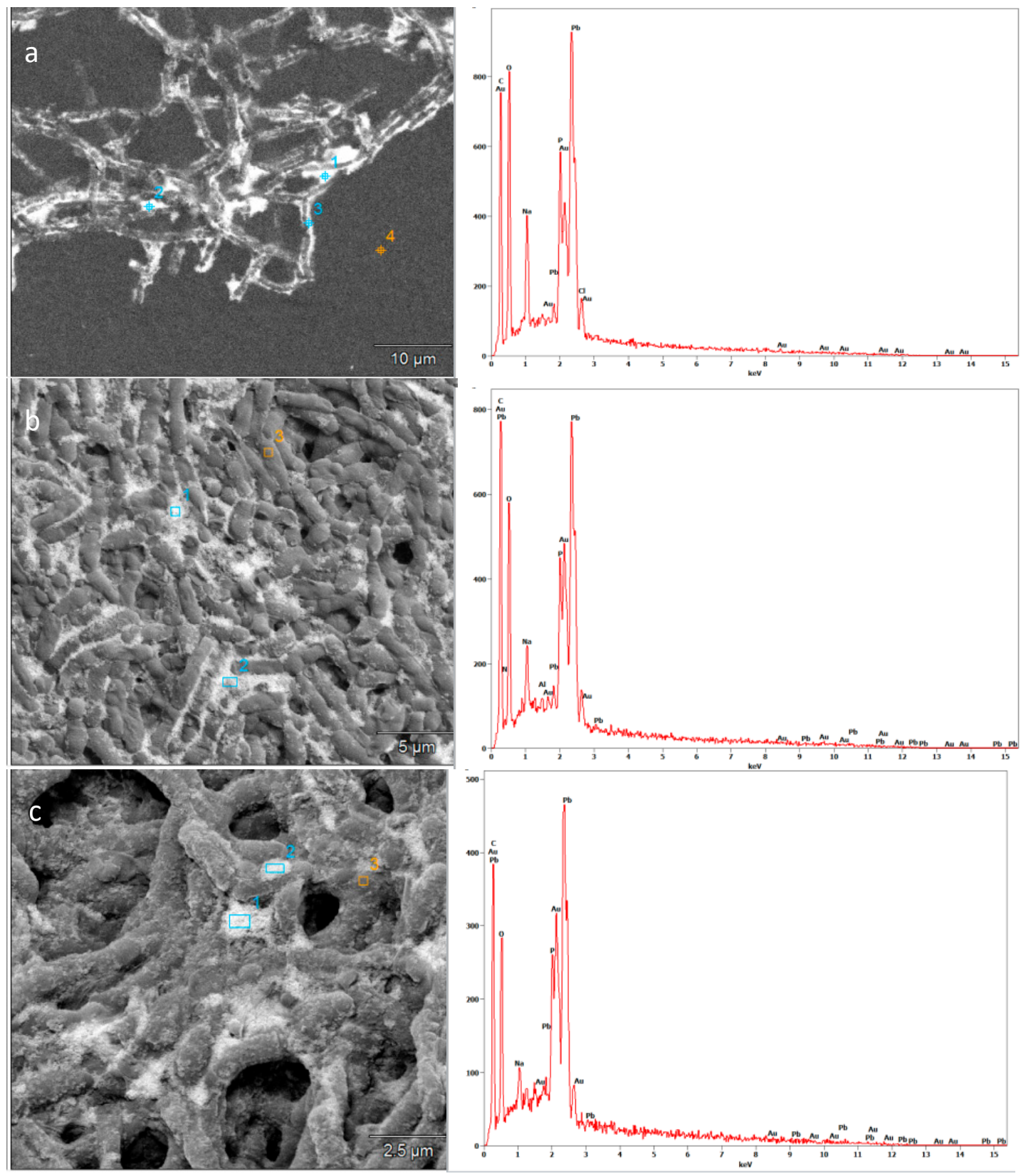

Figure 2. Cont. 

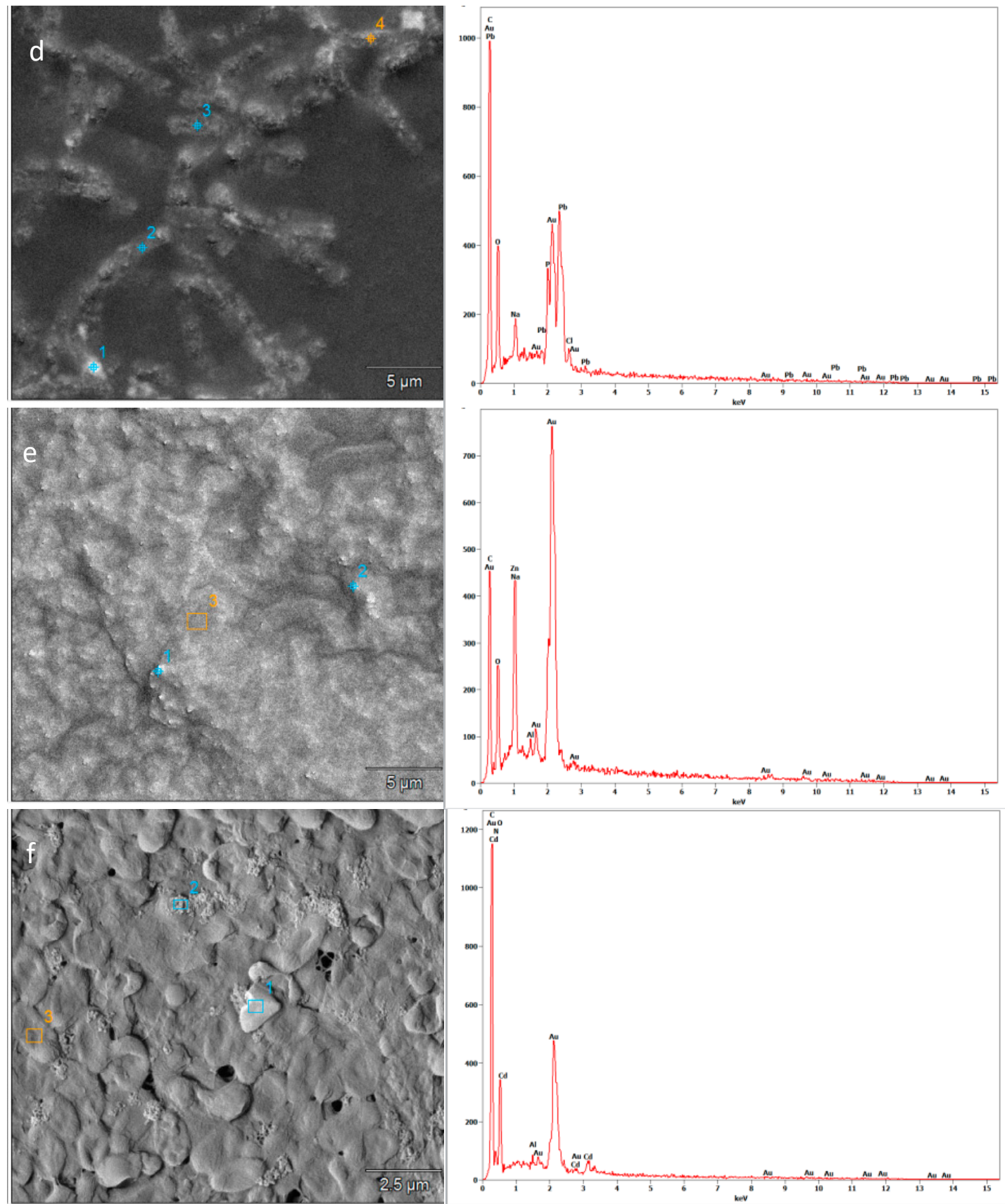

Figure 2. SEM images of bacterial colonies (a) B. paramycoides ST4 (b) B. proteolyticus ST9 (c) B. wiedmnni ST29 (d) Brevibacterium frigoritolerans ST30 (e) Cellulosimicrobium cellulans ST54 (f) Methylobacterium ST85. Numbers in blue colour follow by squares or dots represent the specific locations where EDX-spectra were taken, characterised by more electron dense (bright) metal plaques on the bacterial cells, while the orange area, is a reference location, either background or bacterial cell surface outside of a bright area. Next to each SEM image is the spectrum correspond to the location number one.

\subsection{Germination and Growth Promotion on Vertical Agar Plates (VAPs)}

After $48 \mathrm{~h}$ of incubation, germination of $H$. annuus seeds inoculated with the different strains was $20 \%-80 \%$ higher in comparison to the control seeds (Figure 3). However, some bacterial strains inhibited plant biomass development at the inoculum concentration of $10^{9} \mathrm{CFU} \mathrm{mL} \mathrm{m}^{-1}$ that was used. After two weeks, seedlings inoculated with Klebsiella varicola ST106, Achromobacter sp. ST95, Bacillus cereus ST90, Pseudobacter sp. ST86, Gordonia terrae ST51 and Bacillus simplex ST43 showed a 50\% lower dry weight in comparison to the negative controls. 

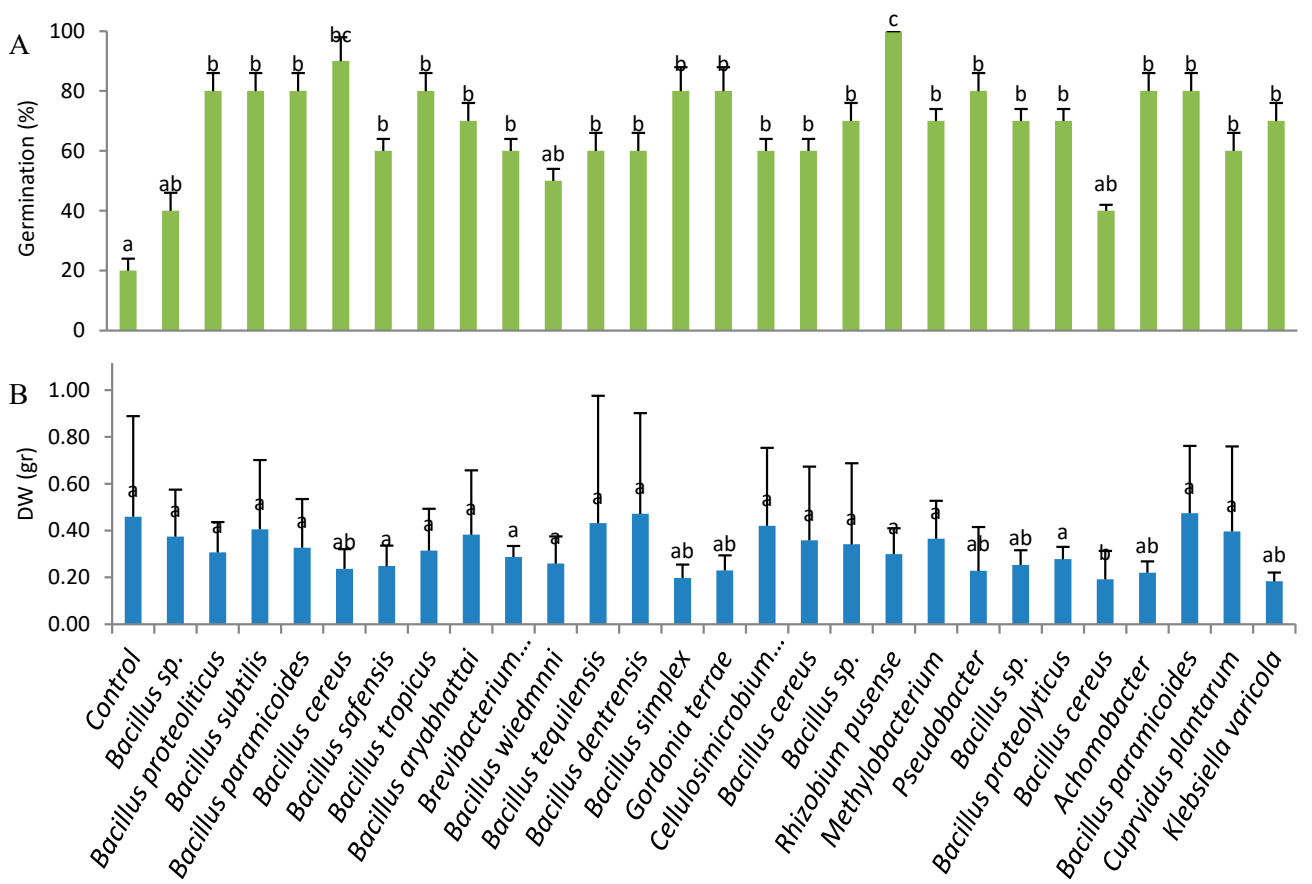

Figure 3. (A) Germination percentage of seeds of H. annuus inoculated with individual strains and (B) biomass development as total dry weight (DW) of plant per plate after two weeks of incubation in VAP systems. Error bars are S.E. $(n=15)$; Values followed by the same letter(s) are not significantly different at $p \leq 0.05$ by Anova and Tukey test.

\subsection{Growth Promotion and Element Bio-Accumulation in Microcosm Systems}

H. annuus seedlings were planted into pots filled with trace element polluted military soil and inoculated respectively with Bacillus paramycoides ST4, Brevibacterium frigoritolerans ST30, Bacillus wiedmannni ST29, Cellulosimicrobium cellulans ST54, Methylobacterium sp. ST85 and Bacillus proteolyticus ST9. After 35 days, plants were harvested, and biomass parameters were determined (Table 3). The stem length of plants inoculated with Bacillus proteolyticus ST9 was 57\% higher compared to the control plants. Furthermore, Bacillus proteolyticus ST9 bio-accumulation factors (BAF) of $\mathrm{Pb}$ and Cd were respectively $20 \%$ and $40 \%$ lower. Also, inoculation with Bacillus wiedmanni ST29 lowered the bioaccumulation of $\mathrm{Cd}$ by $40 \%$. Inoculation with Cellulosimicrobium cellulans ST54, on the contrary, increased the accumulation factor of $\mathrm{Pb}$ six times and of $\mathrm{Cd}$ even 15 times compared to non-inoculated control plants. Also, Bacillus paramycoides ST4 increased the trace element accumulation factors: a factor three for $\mathrm{Pb}$ and a factor six for $\mathrm{Cd}$.

Table 3. Stem length $(\mathrm{cm})$, dry weight $(\mathrm{g})$, concentrations $\left(\mathrm{mg} \mathrm{g}^{-1}\right)$ and Bio-Accumulation Factors (BAF) of $\mathrm{Pb}$ and $\mathrm{Cd}$ in roots and leaves of $\mathrm{H}$. annuus seedlings inoculated with $\mathrm{PGP}, \mathrm{Pb}-$, and Cd-tolerant bacterial strains.

\begin{tabular}{|c|c|c|c|c|c|c|c|c|}
\hline \multirow{2}{*}{ Strain } & \multirow{2}{*}{$\begin{array}{c}\text { Stem } \\
\text { Length }(\mathrm{cm})\end{array}$} & \multirow{2}{*}{$\begin{array}{l}\text { Dry Weight } \\
\text { Stem }(\mathrm{g})\end{array}$} & \multicolumn{2}{|c|}{$\mathrm{Pb}\left(\mathrm{mg} \mathrm{Kg}{ }^{-1}\right)$} & \multicolumn{2}{|c|}{$\mathrm{Cd}\left(\mathrm{mg} \mathrm{Kg}^{-1}\right)$} & \multicolumn{2}{|c|}{ BAF } \\
\hline & & & Root & Leaves & Root & Leaves & $\mathrm{Pb}$ & $\mathrm{Cd}$ \\
\hline Bacillus paramycoides ST4 & 4.7 & $2.00 \pm 1.03$ & $21.40 \pm 1.61$ & $9.06 \pm 1.60$ & $0.31 \pm 0.23$ & $0.02 \pm 0.04$ & $3.14 \mathrm{c}$ & $25.63 \mathrm{~d}$ \\
\hline Bacillus wiedmanni ST29 & 5.7 & $1.14 \pm 0.35$ & $40.14 \pm 5.88$ & $12.97 \pm 4.96$ & $<\mathrm{DL}^{\mathrm{a}}$ & $0.24 \pm 0.19$ & $1.09 \mathrm{ab}$ & 2.46 \\
\hline $\begin{array}{c}\text { Brevibacterium } \\
\text { frigoritolerans ST30 }\end{array}$ & 7.3 & $2.21 \pm 1.40$ & $55.90 \pm 18.93$ & $4.95 \pm 3.22$ & $0.02 \pm 0.31$ & $0.22 \pm 0.05$ & $1.66 \mathrm{~b}$ & $4.83 \mathrm{~b}$ \\
\hline $\begin{array}{l}\text { Cellulosimicrobium } \\
\text { cellulans ST54 }\end{array}$ & 6.3 & $1.86 \pm 0.93$ & $35.77 \pm 6.74$ & $3.62 \pm 1.25$ & $0.33 \pm 0.48$ & $0.17 \pm 0.12$ & $6.17 \mathrm{~d}$ & $61.28 \mathrm{e}$ \\
\hline $\begin{array}{l}\text { Methylobacterium sp. } \\
\text { ST85 }\end{array}$ & 5.3 & $1.66 \pm 1.11$ & $20.02 \pm 1.51$ & $3.51 \pm 2.77$ & $0.51 \pm 0.17$ & $0.14 \pm 0.02$ & $1.84 \mathrm{~b}$ & $18.69 \mathrm{c}$ \\
\hline Bacillus proteolyticus ST9 & 11.0 & $2.50 \pm 0.51$ & $15.60 \pm 1.54$ & $3.40 \pm 1.03$ & $0.37 \pm 0.26$ & $0.21 \pm 0.08$ & $0.73 a$ & $2.45 \mathrm{a}$ \\
\hline Control & 7.0 & $1.85 \pm 0.43$ & $28.89 \pm 2.04$ & $3.87 \pm 1.25$ & $0.43 \pm 0.25$ & $0.08 \pm 0.01$ & $0.92 \mathrm{a}$ & $4.15 \mathrm{~b}$ \\
\hline
\end{tabular}

Values are mean \pm S.E. $(n=6)$; BAF values in the same column followed by the same letter(s) are not significantly different at $p \leq 0.05$ by Anova and Tukey test; ${ }^{a}<\mathrm{DL}$ : below detection limit $(0.05 \mathrm{mg} / \mathrm{kg})$; in grey are highlighted strains that colonized $H$. annuus plants. 


\subsection{Bacterial Survival and Colonization of Plant Tissues in Microcosms-ARISA}

Community-specific profiles obtained from rhizosphere (soil) and root endosphere (root) of the plants that were inoculated in greenhouse were compared with the profiles obtained for each strain individually (blue arrow) to estimate survival and colonization (Figure 4).

Cellulosimicrobium cellulans ST54, Brevibacterium frigoritolerans ST30 and Methylobacterium ST85 apparently did not colonize the $H$. annuus root endosphere and also did not survive in the rhizosphere. Cellulosimicrobium cellulans ST54 was also not detected in control plants growing in polluted soil not inoculated and not sterilized (Figure 4, heatmap G). Taken together, this suggests that this strain should be highly host specific and can only colonize the plant species from which it was isolated. Because the trace element tolerant strains used in this work did not originate from H. annuus, but from H. petiolaris, the metabolites produced by this species probably did not act as effective attractants for this strain.

A significant increase in the accumulation factor of $\mathrm{Pb}$ and $\mathrm{Cd}$ was found on those plants inoculated with Cellulosimicrobium cellulans ST54 even when this strain was not present on the community profiles. However other strains were found colonizing these plants and could be responsible for the increase in the bioaccumulation.

The other strains could be detected in both, root endosphere and rhizosphere 35 days after inoculation. Control plants (not inoculated) grown in polluted soil were also colonised by the same species: Baclilus paramycoides, Methylobacterium and Bacillus proteolyticus were found in the root endosphere and Bacillus wiedmannii was detected in the rhizosphere.

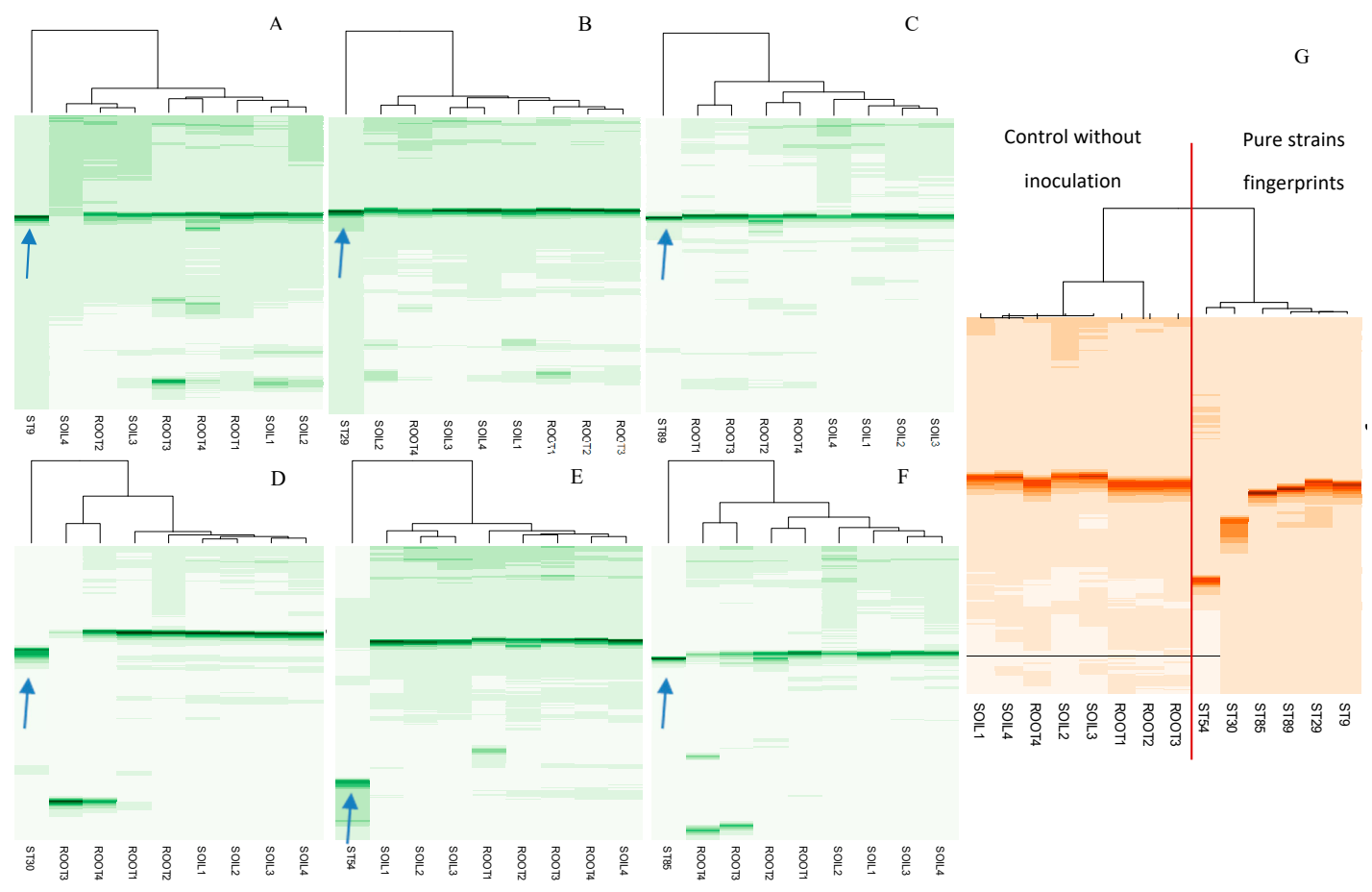

Figure 4. Heatmaps of strain recolonization in rhizosphere (soil) and root endosphere (root) of (A) $B$. paramycoides ST9 (B) B. wiedmannii ST29 (C) B. proteolyticus ST89 (D) Brevibacterium frigoritolerans ST30 (E) Cellulosimicrobiumcellulans ST54 (F) Methylobacterium ST85. Blue arrows indicate the pure inoculated strain fingerprint. (G) Control plants growing in polluted soil without inoculation and pure strains fingerprints. A complete linkage algorithm was used to perform a cluster analysis of Bray-Curtis dissimilarity matrices inferred from the ARISA value.

\section{Discussion}

One hundred and five endophytic and rhizospheric trace element-tolerant bacteria were isolated from roots of $H$. petiolaris plants, grown in $\mathrm{Pb} / \mathrm{Cd}$ polluted soils. To the best of our knowledge, there are 
no earlier reports about the isolation of endophytic and rhizospheric bacteria from this plant species. Though, there exist many studies reporting the isolation of trace element tolerant bacteria from other species such as Arabidopsis [31], Brassica napus [32,33], Thlaspi (syn. Noccaea) caerulescens [34], Nicotiana tabacum [35]. However, some bacteria genera isolated in our study (i.e., Bacillus, Mhetylobacterium, Cellulosimicrobium and Rhizobium) have already been reported in studies made on other plants species harvested from trace elements polluted soils [36-41].

Most earlier reports found that bacterial density/diversity decreases from outside to the root interior [42,43], while in our study the number of cultivable trace element tolerant strains isolated from the root endosphere of $H$. petiolaris plants was almost double that isolated from the rhizosphere.

The PGP traits of the bacterial isolates were determined to identify the most promising strains to improve plant survival and to promote element phytostabilization or extraction. Almost $90 \%$ of the isolates acidified the medium in our report, which directly influenced element solubility. These strains were organic acid producers or biofilm producers and most of them also solubilised phosphate. Several authors relate the solubilisation of inorganic insoluble phosphate by microorganisms to the production of organic acids and chelating oxoacids from sugars [44]. Siderophores production was another capability found in those strains that modified $\mathrm{pH}$ of the medium and the element bioavailability. It has been demonstrated that siderophores can complex a variety of trace element ions, and biosurfactants which enhance trace element removal from polluted soils [45]. B. proteolyticus ST89 significantly increased shoot biomass of $H$. annuus in the greenhouse and in vitro it was one of the strains that produced more IAA. Production of IAA by strains from the rhizosphere and endosphere of different crops, peanut, maize, wheat, and rice was already reported in a number of studies [31,46]. Biofilm producing strains were sought due to their ability to enhance bacterial attachment to the roots and concentrate trace elements into their extracellular polymeric structure [47,48]. However, in our report one of the strains that in vitro was one of the highest biofilm producers (Cellulosimicrobiumcellulans ST54) was not able to colonize H. annuus rhizosphere in the greenhouse.

Interaction between trace elements and the components of the medium played an important role in the sequestration of the trace elements in our in vitro study. $\mathrm{Pb}$ precipitation is common in culture media as $\mathrm{Pb}$ readily complexes with phosphates and hydroxides [38]. In vitro trace element uptake by our isolates in culture media indicated that the strains modified the $\mathrm{pH}$ and the element solubility, making them more or less bioavailable for sequestration or internalization. Some Pseudomonas and Bacillus have been reported to perform maximum removal in the $\mathrm{pH}$ range of 6-8 [49,50] and Klebsiella sp. was reported by Prapagdee et al., 2013 [51] to remove 62\% of Cd at an ion concentration of $25 \mathrm{mg} \mathrm{L}^{-1}$.

In vitro inoculations of $H$. annuus seeds on VAPs showed the capability of some of our strains to enhance germination and development of seedlings. Increased plant growth after bacterial inoculation was reported to be mainly due to the synthesis of plant growth compounds such as IAA and ACC-deaminases, which stimulate elongation of shoots and roots [52,53]. Nevertheless, too high IAA concentrations can result in an unbalanced plant growth or in deleterious effects on root development [54]. In our study, Klebsiella varicola ST106 produced the highest concentrations of IAA (Table 2) and this strain had some of the most adverse effects on plant biomass development (Figure 3).

This is the first report describing the effects of Bacillus paramycoides and Bacillus proteolyticus on plant growth promotion and trace element uptake of plants in microcosm systems. Bacillus wiedmanni isolated from a landfill with electrical waste in China was earlier described by Chen et al., (2018) [55] as a species able to reduce Pd (II) under both aerobic and anaerobic conditions. Methylobacterium sp. was isolated by Koo et al., (2007) [56] from the rhizosphere of plants growing in crude oil and trace element polluted soil and Madhaiyan et al., (2007) [57] reported that inoculation with methylotrophic bacteria decreased trace element uptake by tomato plants and at the same time increased plant biomass. Cellulosimicrobium sp. was reported by Karthik et al., 2017 [58] as a Cr-reducing bacterium able to promote plant growth of alfalfa under trace element stress conditions and to enhance alfalfa trace element uptake. Our study is the first report about $\mathrm{Pb}$ tolerance of Cellulosimicrobium cellulans. 
Despite the high PGP potential of some strains as confirmed under laboratory conditions, the results of pot and/or field experiments are often ambiguous [59]. In our study strains that displayed in vitro PGP capabilities, didn't express it when they were inoculated in the greenhouse. The interaction between the inoculated strain(s) and the autochthonic soil microbiota is an important factor that influences the success of bioaugmentation [60].

The complexity of the interaction between microorganisms, soil and plants was highlighted by Ghasemi et al. (2018) [61], who found that strains isolated from the rhizosphere of Odontarrhena serpyllifolia supported the phytoextraction of $\mathrm{Ni}$ by different Odontarrhena species (O. bracteata, O. inflata, O. serpyllifolia) with different efficiencies, which was dependent on the plant species, soil type, and bacterial inoculant.

\section{Conclusions}

This research provides a collection of $\mathrm{Pb}$ and $\mathrm{Cd}$ tolerant-PGP bacterial strains. Among those, we selected six promising strains, Bacillus paramycoides ST9, Bacillus wiedmanni ST29, Bacillus proteolyticus ST89, Brevibacterium frigoritolerans ST30, Cellulosimicrobiumcellulans ST54, Methylobacterium sp. ST85 and used them in microcosm experiments. They showed high colonisation capabilities after inoculation, colonising the root endosphere of $H$. annuus. Inoculation with B. proteolyticus ST89 significantly increased shoot biomass and lowered trace elements uptake from a polluted military soil. This strain is promising for application in crops that are cultivated in moderately trace element polluted soils to improve plant growth under such harsh field conditions ensuring food security. Inoculation with B. paramycoides ST9, on the other hand, led to an increase of $\mathrm{Pb}$ and $\mathrm{Cd}$ concentrations in $\mathrm{H}$. annuus seedlings, so we do not recommend this strain to be inoculated in crops, but it could be used in other plant species for phytoextraction. Further studies are needed to elucidate the interaction mechanisms between these bacterial strains, trace elements, and plants. In the future, inoculation experiments with consortia will be performed to assess the potential of these promising strains in both phytostabilization and phytoextraction, depending on the remediation strategy that will be chosen.

Supplementary Materials: The following are available online at http://www.mdpi.com/2073-4395/10/2/204/s1. Table S1: Strain identification based on the $16 \mathrm{~S}$ rRNA partial sequence.

Author Contributions: Formal analysis, J.d.; Investigation, L.F. and P.G.; Methodology, V.I.; Writing—original draft, A.S.; Writing—review \& editing, L.J.M., J.V. and S.T. All authors have read and agreed to the published version of the manuscript.

Funding: This research was funded by the UHasselt-Methusalem project 08M03VGRJ, as got an UHasselt BOF-BILA grant in the frame of collaboration between Hasselt University, Belgium and the University of Buenos Aires, and Ibero-American Development Bank under FONTAGRO project ATN/RF-16110-RG.

Acknowledgments: The University of Hasselt, Belgium is greatly appreciated for its financial support.

Conflicts of Interest: The authors declare no conflict of interest.

\section{References}

1. Rizwan, M.; Ali, S.; Rizvi, H.; Rinklebe, J.; Tsang, D.C.; Meers, E.; Ok, Y.S.; Ishaque, W. Phytomanagement of heavy metals in contaminated soils using sunflower: A review. Crit. Rev. Environ. Sci. Technol. 2016, 46, 1498-1528. [CrossRef]

2. Tchounwou, P.B.; Yedjou, C.G.; Patlolla, A.K.; Sutton, D.J. Heavy Metals Toxicity and the Environment; Springer: Basel, Switzerland, 2012; Volume 101, pp. 133-164.

3. Parab, H.; Joshi, S.; Sudersanan, M.; Shenoy, N.; Lali, A.; Sarma, U. Removal and recovery of cobalt from aqueous solutions by adsorption using low cost lignocellulosic biomass-coir pith. J. Environ. Sci. Health $A$ 2010, 45, 603-611. [CrossRef] [PubMed]

4. Kalderis, D.; Juhasz, A.L.; Boopathy, R.; Comfort, S. Soils contaminated with explosives: Environmental fate and evaluation of state-of-the-art remediation processes (IUPACtechnical report). Pure Appl. Chem. 2011, 83, 1407-1484. [CrossRef] 
5. Khazaei, M.; Nasseri, S.; Ganjali, M.R.; Khoobi, M.; Nabizadeh, R.; Mahvi, A.H. Response surface modeling of lead, removal by graphene oxide-Fe3O4 nanocomposite using central composite design. J. Environ. Health Sci. Eng. 2016, 14, 1-14. [CrossRef] [PubMed]

6. Ali, H.; Khan, E.; Sajad, M.A. Phytoremediation of heavy metals-Concepts and applications. Chemosphere 2013, 91, 869-881. [CrossRef] [PubMed]

7. Vangronsveld, J.; Herzig, R.; Weyens, N.; Boulet, J.; Adriaensen, K.; Ruttens, A.; Thewys, T.; Vassilev, A.; Meers, E.; Nehnevajova, E.; et al. Phytoremediation of contaminated soils and groundwater: Lessons from the field. Environ. Sci. Pollut. Res. 2009, 16, 765-794. [CrossRef]

8. Greipsson, S. Phytoremediation. Nat. Educ. Knowl. 2011, 2, 7-12.

9. Mendez, M.O.; Maier, R.M. Phytostabilization of mine tailings in arid and semiarid environments-An emerging remediation technology. Environ. Health Perspect. 2008, 116, 278-283. [CrossRef]

10. Lessl, J.T.; Luo, J.; Ma, L.Q. Pteris vittata continuously removed arsenic from non-labile fraction in three contaminated-soils during 3.5 years of phytoextraction. J. Hazard. Mater. 2014, 279, 485-492. [CrossRef]

11. Adamidis, G.C.; Aloupi, M.; Mastoras, P.; Papadaki, M.I.; Dimitrakopoulos, P.G. Is annual or perennial harvesting more efficient in Ni phytoextraction? Plant Soil 2017, 418, 205-218. [CrossRef]

12. Płociniczak, T.; Sinkkonen, A.; Romantschuk, M.; Sułowicz, S.; Piotrowska-Seget, Z. Rhizospheric Bacterial Strain Brevibacterium casei MH8a Colonizes Plant Tissues and Enhances Cd, Zn, Cu Phytoextraction by White Mustard. Front. Plant Sci. 2016, 7, 101-122. [CrossRef] [PubMed]

13. Gadd, G.M. Microbial influence on metal mobility and application for bioremediation. Geoderma 2004, 122, 109-119. [CrossRef]

14. Jocic, S.; Miladinovic, D.; Kaya, Y. Breeding and Genetics of sunflower. Sunflower: Chemistry, Production, Processing and Utilization; AOCS Press: Urbana, IL, USA, 2015; pp. 187-226.

15. Alaboudi, K.A.; Ahmeda, B.; Brodiec, G. Phytoremediation of $\mathrm{Pb}$ and $\mathrm{Cd}$ contaminated soils by using sunflower (Helianthus annuus) plant. Ann. Agric. Sci. 2018, 63, 123-127. [CrossRef]

16. Govarthanana, M.; Mythilib, R.; Selvankumarb, T.; Kamala-Kannanc, S.; Kima, H. Myco-phytoremediation of arsenic- and lead-contaminated soils by Helianthus annuus and wood rot fungi, Trichoderma sp. isolated from decayed wood. Ecotoxicol. Environ. Saf. 2018, 151, 279-284. [CrossRef] [PubMed]

17. Ramzani, P.M.A.; Khan, W.D.; Iqbal, M.; Kausar, S.; Ali, S.; Rizwan, M.; Virk, Z.A. Effect of different amendments on rice (Oryza sativa L.) growth, yield, nutrient uptake and grain quality in Ni-contaminated soil. Environ. Sci. Pollut. Res. Int. 2016, 23, 18585-18595. [CrossRef] [PubMed]

18. Ahmad, M.S.A.; Ashraf, M.; Hussain, M. Phytotoxic effects of nickel on yield and concentration of macroand micro-nutrients in sunflower (Helianthus annuus L.) achenes. J. Hazard Mater. 2011, 185, 1295-1303. [CrossRef]

19. Saran, A.; Fernandez, L.; Cora, F.; Savio, M.; Thijs, S.; Vangronsveld, J.; Merini, L.J. Phytostabilization of Pb and Cd polluted soils using Helianthus petiolaris as pioneer aromatic plant species. Int. J. Phytoremediat. 2019, 11, 1-9. [CrossRef]

20. Shin, S.H.; Lim, Y.; Lee, S.E.; Yang, N.W.; Rhee, J.H. CAS agar diffusion assay for the measurement of siderophores in biological fluids. J. Microbiol. Meth. 2001, 44, 89-95. [CrossRef]

21. Nguyen, C.; Yan, W.; Le Tacon, F.; Lapayrie, F. Genetic variability of phosphate solubilising activity by monocaryotic and dicaryotic mycelia of the ectomycorrhizal fungus Laccaria bicolor (Maire) P.D. Orton. Plant Soil 1992, 143, 193-199. [CrossRef]

22. Cunningham, J.E.; Kuiack, C. Production of citric and oxalic acids and solubilization of calcium-phosphate by Penicillium bilaii. Appl. Environ. Microbiol. 1992, 58, 1451-1458. [CrossRef]

23. Gordon, S.A.; Weber, R.P. Colorimetric estimation of indole acetic acid. Plant Physiol. 1951, 26, $192-195$. [CrossRef] [PubMed]

24. Romick, T.L.; Fleming, H.P. Acetoin production as an indicator of growth and metabolic inhibition of Listeria monocytogenes. J. Appl. Microbiol. 1998, 84, 18-24. [CrossRef] [PubMed]

25. Belimov, A.A.; Hontzeas, N.; Safronova, V.I.; Demchinskaya, S.V.; Piluzza, G.; Bullitta, S.; Glick, B.R. Cadmium-tolerant plant growth-promoting bacteria associated with the roots of Indian mustard (Brassica juncea L. Czern.). Soil Biol. Biochem. 2005, 37, 241-250. [CrossRef]

26. O'Toole, G.; Kaplan, H.B.; Kolter, R. Biofilm formation as a microbial development. Annu. Rev. Microbiol. 2000, 54, 49-79. [CrossRef] [PubMed] 
27. Sheng, X.F.; Xia, J.J; Jiang, C.Y.; He, L.Y.; Qian, M. Characterization of heavy metal-resistant endophytic bacteria from rape (Brassica napus) roots and their potential in promoting the growth and lead accumulation of rape. Environ. Pollut. 2008, 156, 1164-1170. [CrossRef] [PubMed]

28. Abbas, M.H.H.; Abdelhafez, A.A. Role of EDTA in arsenic mobilization and its uptake by maize grown on an As-polluted soil. Chemosphere 2013, 90, 588-594. [CrossRef]

29. Cardinale, M.; Brusetti, L.; Quatrini, P.; Borin, S.; Puglia, A.M.; Rizzi, A.; Zanardini, E.; Sorlini, C.; Corselli, C.; Daffonchio, D. Comparison of Different Primer Sets for Use in Automated Ribosomal Intergenic Spacer Analysis of Complex Bacterial Communities. Appl. Environ. Microb. 2004, 70, 6147-6156. [CrossRef]

30. Michelland, R.J.; Dejean, S.; Combes, S.; Fortun-Lamothe, L.; Cauquil, L. StatFingerprints: A friendly graphical interface program for processing and analysis of microbial fingerprint profiles. Mol. Ecol. Resour. 2009, 9, 1359-1363. [CrossRef]

31. Truyens, S.; Jambon, I.; Croes, S.; Janssen, J.; Weyens, N.; Mench, M.; Carleer, R.; Cuypers, A.; Vangronsveld, J. The effect of long-term $\mathrm{Cd}$ and $\mathrm{Ni}$ exposure on seed endophytes of Agrostis capillaris and their potential application in phytoremediation of metal-contaminated soils. Int. J. Phytoremediat. 2014, 16, 643-659. [CrossRef]

32. Croes, S.; Weyens, N.; Janssen, J.; Vercampt, H.; Colpaert, J.V.; Carleer, R.; Vangronsveld, J. Bacterial communities associated with Brassica napus L. grown on trace element-contaminated and non-contaminated fields: A genotypic and phenotypic comparison. Microb. Biotechnol. 2013, 6, 371-384. [CrossRef]

33. Montalban, B.; Croes, S.; Weyens, N.; Lobo, M.; Perez-Sanz, A.; Vangronsveld, J. Characterization of bacterial communities associated with Brassica napus L. growing on a Zn-contaminated soil and their effects on root growth. Int. J. Phytoremediat. 2016, 18, 985-993. [CrossRef] [PubMed]

34. Lodewyckx, C.; Mergeay, M.; Vangronsveld, J.; Clijsters, H.; van der Lelie, D. Isolation, characterization, and identification of bacteria associated to the zinc hyperaccumulator Thlaspi caerulescens subsp. calaminaria. Int. J. Phytoremediat. 2002, 4, 101-115. [CrossRef] [PubMed]

35. Mastretta, C.; Taghavi, S.; van der Lelie, D.; Mengoni, A.; Galardi, F.; Gonnelli, C.; Barac, T.; Boulet, J.; Weyens, N.; Vangronsveld, J. Endophytic bacteria from seeds of Nicotiana tabacum can reduce cadmium phytotoxicity. Int. J. Phytoremediat. 2009, 11, 251-267. [CrossRef]

36. Srikakolapu, M.S. Heavy metal tolerance of Bacillus spp. Soc. Sci. Dev. Agric. Tech. 2014, 8, 315-318.

37. Idris, R.; Kuffner, M.; Bodrossy, L. Characterization of Ni-tolerant methylobacteria associated with the hyperaccumulating plant Thlaspi goesingense and description of Methylobacterium goesingense sp. nov. Syst. Appl. Microbiol. 2006, 29, 634-644. [CrossRef] [PubMed]

38. Fomina, M.; Gadd, G.M. Biosorption: Current perspectives on concept, definition and application. Bioresour. Technol. 2014, 160, 3-14. [CrossRef]

39. Sun, Z.; Lv, Y.; Liu, Y.; Ren, R. Removal of nitrogen by heterotrophic nitrificationaerobic denitrification of a novel metal resistant bacterium Cupriavidus sp. S1. Bioresour. Technol. 2016, 220, 142-150. [CrossRef]

40. Cardoso, P.; Corticeiro, S.; Freitas, R.; Figueira, E. Different efficiencies of the same mechanisms result in distinct Cd tolerance within Rhizobium. Ecotoxicol. Environ. Saf. 2018, 150, 260-269. [CrossRef]

41. Remans, T.; Nacry, P.; Pervent, M.; Girin, T.; Tillard, P.; Lepetit, M.; Gojon, A. A central role for the nitrate transporter NRT2.1 in the integrated morphological and physiological responses of the root system to nitrogen limitation in Arabidopsis. Plant Physiol. 2006, 140, 909-921. [CrossRef]

42. Fisher, P.J.; Petrini, O.; Scott, H.M.L. The distribution of some fungal and bacterial endophytes in maize. New Phytol. 1992, 122, 299-305. [CrossRef]

43. Benizri, E.; Baudoin, E.; Guckert, A. Root colonization by inoculated plant growth rhizobacteria. Biocontrol Sci. Technol. 2001, 11, 557-574. [CrossRef]

44. Mehta, S.; Nautiyal, C.S. An Efficient Method for Qualitative Screening of Phosphate-Solubilizing Bacteria. Curr. Microbiol. 2001, 43, 51-56. [CrossRef] [PubMed]

45. Mulligan, C.N. Environmental applications for biosurfactants. Environ. Pollut. 2005, 133, 183-198. [CrossRef] [PubMed]

46. Montalban, B.; Thijs, S.; Lobo, MC.; Weyens, N.; Ameloot, M.; Vangronsveld, J.; Perez-Sanz, A. Cultivar and Metal-Specific Effects of Endophytic Bacteria in Helianthus tuberosus Exposed to Cd and Zn. Int. J. Mol. Sci. 2017, 18, 2026. [CrossRef]

47. Das, N.; Basak, L.V.G.; Salam, J.A.; Abigail, E.A. Application of biofilms on remediationmof pollutants, an overview. J. Microbiol. Biotechnol. 2012, 2, 783-790. 
48. Sessitsch, A.; Kuffner, M.; Kidd, P.; Vangronsveld, J.; Wenzel, W.; Fallmann, K.; Puschenreiter, M. The role of plant-associated bacteria in the mobilization and phytoextraction of trace elements in contaminated soils. Soil Biol. Biochem. 2013, 60, 182-194. [CrossRef]

49. Alkan, H.; Gul-Guven, R.; Guven, K.; Erdogan, S.; Dogru, M. Biosorption of Cd, Cu, and Ni Ions by a Thermophilic Haloalkalitolerant Bacterial Strain (KG9) Immobilized on Amberlite XAD-4. Pol. J. Environ. Stud. 2015, 24, 1903-1910. [CrossRef]

50. Oh, S.E.; Hassan, S.H.; Joo, J.H. Biosorption of heavy metals by lyophilized cells of Pseudomonas stutzeri. World J. Microb. Biot. 2009, 25, 1771-1778. [CrossRef]

51. Prapagdee, B.; Chanprasert, M.; Mongkolsuk, S. Bioaugmentation with cadmium-resistant plant growth-promoting rhizobacteria to assist cadmium phytoextraction by Helianthus annuus. Chemosphere 2013, 92, 659-666. [CrossRef]

52. Zhuang, L.; Zhang, J.; Xiang, X. Point mutations in the stem region and the fourth AAA domain of cytoplasmic dynein heavy chain partially suppress the phenotype of NUDF/LIS1 loss in Aspergillus nidulans. Genetic 2007, 175, 1185-1196. [CrossRef]

53. Ma, Y.; Szostkiewicz, I.; Korte, A.; Moes, D.; Yang, Y.; Christmann, A.; Grill, E. Regulators of PP2C phosphatase activity function as abscisic acid sensors. Science 2009, 324, 1064-1068. [CrossRef] [PubMed]

54. Persello Cartieaux, F.; Nussaume, L.; Robaglia, C. Tales from the underground: Molecular plant-rhizobacteria interactions. Plant Cell Environ. 2003, 26, 189-199. [CrossRef]

55. Chen, Y.; Chen, Y.; Wu, J.; Zhang, J. The effect of biotic and abiotic environmental factors on Pd(II) adsorption and reduction by Bacilius wiedmannii MSM. Ecotoxicol. Environ. Saf. 2018, 162, 546-553. [CrossRef] [PubMed]

56. Koo, S.-Y.; Cho, K.-S. Characterization of a Heavy Metal-Resistant and Plant Growth-Promoting Rhizobacterium, Methylobacterium sp. SY-NiR1. Korean J. Microbiol. Biot. 2007, 35, 58-65.

57. Madhaiyan, M.S.; Poonguzhali, S.; Sa, T. Metal tolerating methylotrophic bacteria reduces nickel and cadmium toxicity and promotes plant growth of tomato (Lycopersicon esculentum L.). Chemosphere 2007, 69, 220-228. [CrossRef]

58. Karthik, C.; Barathi, S.; Pugazhendhi, A.; Ramkumar, S.R.; Dung Thi, N.B.; Arulselvi, P.I. Evaluation of $\mathrm{Cr}(\mathrm{VI})$ reduction mechanism and removal by Cellulosimicrobium funkei strain AR8, a novel haloalkaliphilic bacterium. J. Hazard. Mater. 2017, 333, 42-53. [CrossRef]

59. Płociniczak, T.; Chod, M.; Pacwa-Płociniczak, M.; Piotrowska-Seget, Z. Metal-tolerant endophytic bacteria associated with Silene vulgaris support the $\mathrm{Cd}$ and $\mathrm{Zn}$ phytoextraction in non-host plants. Chemosphere 2016, 219, 250-260. [CrossRef]

60. Pacwa-Płociniczak, M.; Płaza, G.A.; Piotrowska-Seget, Z. Monitoring the changes in a bacterial community in petroleum-polluted soil bioaugmented with hydrocarbon-degrading strains. Appl. Soil Ecol. 2016, 105, 76-85. [CrossRef]

61. Ghasemi, Z.; Ghaderian, S.M.; Rodríguez-Garrido, B.; Prieto-Fernández, A.; Kidd, P.S. Plant species-specificity and effects of bioinoculants and fertilization on plant performance for nickel phytomining. Plant Soil 2018, 425, 265-285. [CrossRef]

(C) 2020 by the authors. Licensee MDPI, Basel, Switzerland. This article is an open access article distributed under the terms and conditions of the Creative Commons Attribution (CC BY) license (http://creativecommons.org/licenses/by/4.0/). 